\title{
Municipalities' own revenue as an instrument for financial independence
}

\author{
Valentina Aleksandrova ${ }^{1}$, Nadezhda Krasteva $^{1}$, Gergana $\mathrm{Kresnaliyska}^{2}$, Yoana Petrova $^{1}$ and \\ Petar Baldzhiev ${ }^{*}$ \\ ${ }^{1}$ South-West University "Neofit Rilski”, Faculty of Law and History, Department of Public Law, 1 \\ Georgi Izmirliev - Makedoncheto Sq., 2700 Blagoevgrad, Bulgaria \\ ${ }^{2}$ South-West University "Neofit Rilski", Faculty of Law and History, Department of National \\ Security and Public Administration, 1 Georgi Izmirliev - Makedoncheto Sq., 2700 Blagoevgrad, \\ Bulgaria
}

\begin{abstract}
.
Research background: The article presents an analysis of the trends relating to the relation of the own income of municipalities and the received from the state budget financial resources compared with other countries which are chosen according to their form of state organization, as well as the financial relations of the municipal budget and the state budget, the budgetary relations and the applied fiscal rules.

Purpose of the article: The topicality of the issues connected with the financial decentralization of municipalities and the existing problems is indisputable, as the analysis and the assessment of the financial independence of municipalities are made according to a basic index - their own income. The main problem that is connected with the independence of municipalities - lack of enough own income requires the exertion of serious efforts so that the financially weaker and local communities are protected. The globalization and the free movement of people have an adverse effect on the own income of the municipalities in the country because of their depopulation and to a large extent, they depend on the state subsidies and transfers which seriously limits their independence.

Methods: The methods of analysis include a comparative one and an analysis of the constitutional and legal organization of municipal budgets in Bulgaria as well as an analysis of the structure of their own income.

Findings \& Value added: The analysis allows us to make suggestions about legal changes and recommendations for more useful budgetary relations between the municipal budgets and the state budget.
\end{abstract}

Keywords: budgetary income; budgetary relations; fiscal rules; budgetary process

JEL Classification: $K 10 ; K 38$

\footnotetext{
*Corresponding author: petarbaldgiev@abv.bg
} 


\section{Introduction}

Local finances in the Republic of Bulgaria have been subject to numerous legislative changes over the last 10 years, which has led to a number of significant steps: steps related to the amendment of the constitution of the Republic of Bulgaria and the provision of tax powers to municipalities; with the adoption of a new ruling and budget law - Public Finance Act; by defining an enhanced role of the European funds provided to the municipalities, by adopting a state program for regional development; with the introduction of a procedure for financial recovery of municipalities according to the provisions of the Public Finance Act. All these legal changes are key to understanding the attitude to the financial decentralization.

"The last decade has been a period during which extremely limited results have been achieved in terms of both financial independence and sustainability of the municipal budget, as well as the opportunities for the municipal budget to influence on the regional development beyond the frameworks of state transfers and European funds" [1]. The Strategy for Decentralization 2016-2025, adopted by the Ministry of Regional Development and Public Works, sets guidelines for continuing the decentralization process, including the increasing of the own revenues by increasing the local tax revenues, restructuring the tax system and introducing new local taxes. Two goals have been formulated to measure the degree of decentralization in Bulgaria: achieving a share of the municipal investments in the investments in the consolidated fiscal program (CFP) - 50\% and a share of own revenues from all budget revenues of municipalities - 50\%. „The planned ratio of the municipal revenues to the gross domestic product (GDP); the share of the municipal costs in all costs in the CFP and the share of the municipal taxes in all tax revenues is respectively $10 \%, 23 \%$ and $15 \%$, respectively" [2].

The main problem connected with the financial independence of municipalities is the lack of enough own revenues for the implementation of local projects and programs or solving local problems. It requires serious efforts for protection of financially weaker local communities and the establishment of appropriate financial mechanisms for the distribution of public funds pursuant to Art. 9 of the European Charter of Local Self-Government. "Effective decentralisation in the political, social and economic spheres depends on the transfer of certain tax instruments to the local tier" [3]. The provision of fiscal competence to municipalities is the basis of fiscal decentralization. "Fiscal decentralization is the process through which specific levels of government decision-making and implementation responsibilities in public finance redistributed to lower levels of government fiscal autonomy upward toward" [4]. The relation to the local government legislation outlines the scope of local competences, but it keeps the unbalanced system of transferred responsibilities for the provision of services, without transferring the necessary decisionmaking powers relating to their provision, as well as provision of resources for their financing. "Practice in many countries tells us that the central level of government in many countries is the one that determines the limits for the lower levels of government, both on the revenues side (determination of tax rates is the domain of the central level of government) and on the expenditures side (decisions regarding the eligibility of expenditures are the domain of the central level of government)" [5]. The enabling of local communities to influence on the determination of the amount of tax revenues and expenditures that they can finance with their own finances will make them more flexible in the implementation of local projects and priorities. "On the other hand, fiscal decentralization may have positive effects on the fiscal performance of the general government. For instance, under some theoretical assumption that local governments are able to supply the public goods more efficiently and to conduct the public policy in more 
transparent and accountable manner than the central government, decentralization increases the overall fiscal performance of the general government".[6]

\section{Methods}

The topicality of the issues relating to the financial decentralization of municipalities and the existing problems in this context is indisputable. For the purposes of the present study, the analysis and assessment of the financial independence of municipalities are made on the basis of one main indicator - their own revenues. The methodology of the study includes a comparative legal analysis of the constitutional and legal framework of municipal budgets in the Republic of Bulgaria and in countries chosen for the purposes of the study, as well as an analysis of the structure of their own revenues and their connection with the national gross domestic product and budget subsidies of the central budget.

The main research task is the study of trends and comparison of the volume of own revenues of municipalities in pre-defined unitary EU member states, as well as studying the applied good practices relating to the increasing of fiscal autonomy and their connection with the process of fiscal decentralization. In order to achieve this goal, the following tasks shall be solved: to choose the countries with which the comparison will be made; to examine the legislation - at a constitutional and legal level, of the fiscal independence of the municipalities of these countries; to determine the criteria on the basis of which the comparison shall be made; to lay down the trends based on the comparison of the selected indicators and to propose motivated suggestions for legislative changes if necessary.

The main division between the municipal revenues in the countries which are subject of the research is their division relating to their own revenues and the state transfers. The chosen indicators for this comparison are:

1. Local revenues and their connection with the gross domestic product;

2. Share of local revenues in the budget and share of state transfers;

3. Share of local tax and non-tax revenues in total revenues.

The following Eastern European member states are chosen to do the analysis: the Republic of Bulgaria, the Slovak Republic, the Republic of Latvia and the Republic of Lithuania, as they have relatively similar budget systems and similar problems in local government and local finances. These are countries with decreasing population - less than 10 million, with the exception of Slovakia, where the number of the population has increased in recent years.

All countries which are chosen for the purposes of the study have recently become members of the EU - 2004-2007. 2017 is taken as an example in order to make a comparison, as a period of 10 years after the accession of the countries in the EU has passed, and for which year there is information about the chosen countries based on the given indicators for making the comparison.

The principle of local self-government is determined by the constitutionally determined in the studied countries according to the requirement of Art. 2 of the European Charter of Local Self-Government.

\section{The constitutional regulation of the local self-government and municipalities' financing}

Republic of Bulgaria. The structure of the budget system of Bulgaria is predetermined by the text of Art. 2, para. 1 of the constitution, according to which the Republic of Bulgaria is a unified country with local self-government where autonomous territorial entities are not allowed. 
Chapter Seven of the constitution is entitled "Local self-government and local administration". Pursuant to Art. 135, para. 1 of the constitution of the Republic of Bulgaria, the territory of Bulgaria is divided into municipalities and regions, and pursuant to Art. 136, par. 1 of the constitution, the municipality is the main administrative-territorial unit where the local self-government is carried out. The National Assembly annually adopts three budget laws, which are submitted by the Council of Ministers - the state budget, the budget of the state social security and the budget of the National Health Insurance Fund. "Through them, he implements the "public administration, whose efficiency and effectiveness is ensured by the administration of the Council of Ministers" [7].

The body of local self-government in the municipality is the municipal council. It is necessary to be mentioned that according to the constitution of the Republic of Bulgaria, the municipal council determines the amount of local taxes under conditions, within the limits established by law, as it also determines the amount of local taxes in a way established by the law (Art. 141, par. 3 and par. 4) and this way is established by the Local Taxes and Fees Act.

The budget policy of the country "without which "the very existence of the state is inconceivable" is determined annually with the Budget Act of the Republic of Bulgaria for the respective year, and at a local level - with the decisions of the municipal councils which adopt the annual municipal budget as "a part of public finances ... in the consolidated fiscal programme“ [8].

Slovak Republic. The acting constitution of the Slovak Republic was adopted in 1992. It states that Slovakia is a parliamentary republic.

Chapter Three, part one of the constitution of the country is entitled: "The Economy of the Slovak Republic". This chapter regulates the financing of local government structures, the ways for their provision with the necessary funds for efficient operation and support, etc. The provision of Art. 58 of the constitution states that the financial management of the Slovak Republic is carried out through its state budget. Part Two of the abovementioned chapter also presents the body that exercises control over the management of budget resources approved in accordance with the law of the national council of the Slovak Republic or the government - The Supreme Audit Office of the Slovak Republic. It is an independent body that monitors the flow, expenditure and accounting of the financial resources of the countries and municipalities.

Chapter Four of the Slovak constitution is entitled: "Territorial self-government"[9]. It (Art. 64) is regulated that the municipality is the main element of territorial selfgovernment. Territorial self-government includes a municipality and a higher territorial unit. The provision of Art. 65 of the constitution introduces the operational financial independence of the municipalities, specifying that the municipality and the higher territorial unit are legal entities which under determined by the law conditions independently manage their own property and financial resources "using the experience of the private sector" [10].

Republic of Latvia. The Republic of Latvia is a democratic parliamentary republic. The constitution of the Republic of Latvia does not contain provisions governing the issues related to the local self-government in the country. The adopted in 1995 Local Authorities Act contains the rules governing the formation of the administrative structure of local authorities. The Law also states that the economic basis of the local self-government is property, including different financial resources.

The constitution of the Republic of Latvia does not contain provisions related to the budget system. There is a special law regulating the procedures for formulation, approval and implementation of the state budget and the budgets of the local self-government and the responsibility in the budget process - Budget and Finance Management Act. 
Republic of Lithuania. The Republic of Lithuania is a semi-presidential republic. The constitution of the Republic of Lithuania was adopted in 1992. In chapter Ten which is entitled "Local Self-Government", what is first guaranteed is the right of self-government of the administrative-territorial units of the country enshrined in law (Art. 119).

The provision of Art. 121 of the constitution regulates the way of financing the municipalities in the Republic of Lithuania. They prepare and approve their own budgets. Municipal councils have the right, within the limits and in accordance with the provided by the law procedure, to establish local levies (receivables). Municipal councils can also determine taxes and can impose tax reliefs at the expense of their own budgets. Article 127 of the constitution describes the budget system of the Republic of Lithuania. According to the text, it consists of the independent state budget of the Republic of Lithuania and independent municipal budgets. State budget revenues are collected from taxes, compulsory payments, levies, state property revenues and other revenues. Taxes, other payments to budgets and levies are determined by the laws of the Republic of Lithuania.

\section{Results and Discussions}

Analysis of the data related to the criterion for local revenues and their connection with the gross domestic product. One of the indicators that present the degree of fiscal decentralization is the revenues for local authorities in the national budget and the gross domestic product (GDP) of the country. "From the Eurostat data it can be concluded that the "richer" European countries also have a higher share of municipal revenues in GDP. According to this indicator, the Scandinavian countries (Denmark, Sweden, and Finland) are in the forefront, as they are also characterized with the highest degree of decentralization. Bulgaria ranks 17 th out of 25 countries. It can be seen that before it from Eastern Europe there are all countries except for Slovakia. "The countries after Bulgaria do no conduct a policy of decentralization" [11].

The main positive change in Bulgaria during the period of application of the First Program for Implementation of the Decentralization Strategy 2006-2009 is granting tax powers to municipalities. The amendments of the constitution enabled the municipalities to conduct a real financial policy from the beginning of 2000 by setting the rates of local taxes within the limits set by the law. The main results of the changes are the achievement of an $8 \%$ share of municipal revenues to gross domestic product (GDP) and a $20 \%$ share of municipal expenditures in the total public expenditures of the country (2008). Positive structural changes in local finances have been made. The share of own revenues reached $35.8 \%$ (2007) and of investments $-28.6 \%$ of all municipal expenditures.

The analysis of the data related to the revenues of the municipal budget in Lithuania evidences for the good financial independence of the local authorities. However, it would be a mistake to conclude that Lithuanian local authorities are financially strong and that the financial resources are sufficient for the implementation of a predetermined function because in recent years the budget revenues of the local government have been growing in comparison with GDP, as on average basis they are only $10 \%$ of GDP, and the budget transfers in the form of subsidies and grants are about $88 \%$. Thus, if the degree of fiscal decentralization is calculated according to the ratio of the revenues between the local budgets and the national budget, Lithuania can be classified as a significantly decentralized country. However, if the ratio between the revenues between the local budgets and GDP is calculated, it will be seen that in this respect there is a low degree of decentralization in Lithuania. "The degree of fiscal decentralization of certain governments is estimated by the proportion of local government involvement in total revenues and expenditures of the general government and the local government share in GDP" [12]. 
The formation of territorial self-government in the Slovak Republic has undergone a continuous development which has been influenced by many political and social events. The processes and the reforms that have led to greater autonomy of municipalities and regions are part of the process of political, economic, social and cultural renewal of territorial communities.

"...The reasons for decentralization are different in different countries. Efforts to democratize their own political systems are characteristic for post-Soviet countries of Eastern Europe". [13] "Most Eastern European countries started the transition process by restructuring their political, economic and state systems as a reaction to the political and economic failure of the former authoritarian centralized systems. Since there is no optimal degree of fiscal decentralization, the level of decentralization has primarily been shaped by political, historical and ethnic realities, and its eff ectiveness has been influenced by the institutional design and capacities of the various levels of government". [14] "Sufficient level of competencies and resources that have been transferred to the local level represent another step further to democratic society. Bringing the decision-making process closer to the citizens also becomes an important issue for the EU countries concerning deepening the integration at the level of local self-government and fiscal decentralization" [15].

Table 1. Subnational government revenue - 2017

\begin{tabular}{|c|c|c|c|c|}
\hline Country & $\begin{array}{c}\text { EUR } \\
\text { billions }\end{array}$ & $\begin{array}{c}\text { EUR } \\
\text { per capita }\end{array}$ & \% GDP & \% public revenue \\
\hline Bulgaria & 3.7 & 519 & $7.3 \%$ & $20.2 \%$ \\
\hline The Slovak Republic & 5.9 & 1076 & $6.9 \%$ & $17.5 \%$ \\
\hline Latvia & 3.3 & 1170 & $8.0 \%$ & $23.6 \%$ \\
\hline Lithuania & 2.7 & 1379 & $10.0 \%$ & $26.7 \%$ \\
\hline
\end{tabular}

Source: OECD

Analysis of the data related to the criterion for the share of local revenues in the budget and share of state transfers. Despite the years of attempts connected with the decentralization and increasing the autonomy of municipalities in the Republic of Bulgaria, to a great extent they still remain financially dependent on the central budget. If on the basis of the statistical data an average profile of municipal revenues is made, it will be noticed that about $60 \%$ of all revenues are in fact transfers from the state budget. The own revenues of the municipalities averagely amount to only about $35 \%$, where the smaller part of the same have a tax and the greater part have a non-tax origin. "Large transfers from the centre are a clear indicator of a high degree of dependence and a sign of weakness in terms of subnational resources" [16].

The meaning of providing subsidies to municipalities is presented in the following directions:

1. Subsidies overcome the imbalance between the different levels of government and it ensured sufficient funding for local authorities.

2. The subsidies overcome the imbalance between the different municipalities through a mechanism which shall ensure that the residents of each municipality will be able to use the same public services at an affordable and approximately the same price.

3. Subsidies ensure minimum levels of public services provided at a local level, setting uniform spending standards for the financial provision of such services, such as education, health care, social security, etc.

4. The subsidies multiply the efficiency of the services used on the territory of one municipality, where the same are offered by the respective local administration, but they also reach the residents of neighbouring municipalities - for example the installed drinking or wastewater treatment plant, the greater number of schools, green areas, street lighting, 
museums, sports facilities, etc. They will also benefit the residents of the surrounding municipalities, not only the one in which they are located [17].

The structure of the own revenues of the Bulgarian municipalities during the period 2010-2017 in Bulgaria shows a tendency of increasing, ranging from $35.7 \%$ to $41.3 \%$ during the period. The relative share of non-tax revenues is predominant, with a tendency to gradually decreasing, as from $63.2 \%$ of the total amount of own revenues and grants in 2010 it decreased to $56.8 \%$ in 2017 , and the share of grants compared to the total revenues of the municipal budgets is insignificant and fluctuates in the range of $1.1 \%$ to $3.3 \%$ during the examined period [18].

The published reports of the Ministry of Finance of the Republic of Bulgaria, pursuant to Art. 130f, para. 4, in connection with Art. 130g of the Public Finance Act shows that the average share of revenues in total revenues for the country in 2018 decreased to $36.65 \%$, compared to $38.39 \%$ at the end of 2017 . The national average share of coverage of expenditures for local activities with revenues decreased to $82.38 \%$, compared to $88.39 \%$ in 2017, as 57 municipalities achieved a result above the national average (49 at the end of 2017). Regarding the budget balance compared to the total revenues according to the report - the average level for the country at the end of 2018 is $1.70 \%$ (as it was $3.85 \%$ at the end of 2017). The number of municipalities reporting a result above the average at the end of 2018 is 156 and is higher than those at the end of 2017, when the municipalities were 111. It shall be noted that the budget balance of municipalities at the national level in 2018 is positive. That is why its share in total revenues is positive. The national average level of debt, as a percentage of planned revenues, equalization subsidy and other transfers for local activities from the central budget, increased to $50.25 \%$ (compared to $48.08 \%$ in 2017) and it is relatively stable.

From the data for the first quarter of 2020 compared to the end of 2019 , as well as compared to the same period of 2019 , it becomes clear that the average share of revenues in total revenues for the country decreased to $29.47 \%$ compared to $34.92 \%$ in end of 2019 , as it is lower in comparison with the same period of the last year $(33.60 \%)$. The national average level of debt, as a percentage of planned revenues, equalization subsidy and other transfers for local activities from the Central Bank, decreased to $46.49 \%$ compared to $48.50 \%$ a year earlier, remaining lower than at the end of $2019-48.49 \%$. As of the end of March 2020, the budget balance of the municipalities is positive and it amounts to BGN 314.2 million.

The ratio between the local government's own revenue and the state subsidies characterizes the degree of independence of the local government.

Analysis of the data relating to the criterion for the share of local tax and non-tax revenues in the total revenues. To assess the powers of the local authorities over the budget revenues, a key indicator is used being the share of own revenues in all municipal revenues. For the countries studied, it is as follows:

Table 2. Subnational government tax revenue- 2017

\begin{tabular}{|c|c|c|c|c|c|}
\hline Country & $\begin{array}{c}\text { EUR } \\
\text { billions }\end{array}$ & $\begin{array}{c}\text { EUR } \\
\text { Per capita }\end{array}$ & \% GDP & \% subnational revenue & \% public revenue \\
\hline Bulgaria & 0.5 & 67 & $0.9 \%$ & $12.8 \%$ & $4.4 \%$ \\
\hline The Slovak Republic & 0.4 & 80 & $0.5 \%$ & $7.4 \%$ & $2.8 \%$ \\
\hline Latvia & 1.6 & 829 & $6.0 \%$ & $60.1 \%$ & $26.7 \%$ \\
\hline Lithuania & 0.1 & 52 & $0.4 \%$ & $4.4 \%$ & $2.1 \%$ \\
\hline
\end{tabular}

Source: OECD 
It is obvious that in Latvia this indicator is at a relatively good level, but for other countries it is catastrophic - below or equal to 0.5 billion euros. The same finding applies to the indicator measured in euro per capita and the other three indicators. From this indicator it can be concluded that the ability of local authorities to influence on the type and volume of local revenues through local taxes is practically minimal. This limits to a maximum extent the possibility for the municipalities to have their own social, economic or other policy, different or distinguishing from the national one

\section{Conclusions}

Financial decentralization is the provision of resources, the transfer of resources, rights for determining their amount, the way the same ones are used and the transfer of responsibilities for financing public services by local communities. "Such relations imply a different level of distribution of the base of forming financial resources between the state (central) budget and local budgets" [19]. In this sense, the degree of financial decentralization is determined by:

- the available type of resources entering the budget of the lower level of territorial government and its powers for their determination, i.e. by the type of revenues and revenue powers;

- the ability of the lower level of territorial government to use the available resources, i.e. its expenditure rights and responsibilities.

The powers of the revenues of the local authorities are connected with the availability of own revenues, with the possibility for determination of their type and amount; receiving financial resources from property management and disposal; the possibility for organization, collection and using financial resources from the consumers/ local community; planning and administration of own revenues; the types of subsidies and other transfers of higher levels of government; the ways for their determination and distribution, the degree of freedom relating to their usage, the possibilities for crediting.

Expenditure rights and responsibilities of local governments are associated with the possibility of: planning expenditures; the right of keeping the current savings and the transitional balance; redistribution of finances between functions, activities, type of expenses; availability of investment resources; delegation of finances to external contractors; financial control of the use of finances.

From the analysed data it can be concluded that in the Republic of Bulgaria the share of local revenues in the budget decreased between 2015 and 2017, both as a percentage of GDP and total public revenues, and this is a trend that still exists now in 2020. In comparison with the other 4 countries and in respect of the indicators selected for comparison, the Republic of Bulgaria is either in third or fourth place - before Lithuania or Latvia. This puts it in an unenviable place even among these countries, and when compared to the leading countries in financial decentralization in the European Union, this position would be more than unsatisfactory.

The municipalities in Bulgaria are seriously insufficiently self-financing. Their fiscal autonomy is significantly reduced.

These conclusions coincide with the conclusions made in the report Fiscal Decentralization Indicators for South-East Europe of Network of Associations of Local Authorities of South East Europe /NALAS/ [20], prepared with the use of similar indicators for comparison between the countries from Southeast Europe.

Local authorities in the compared countries continue to face similar challenges for generating their own revenues, regardless of the level of development of their economy and their membership in the European Union. 
The analysis allows us to formulate suggestions for legal changes and recommendations for more effective budget relations of municipal budgets with the state budget.

For example, we consider it appropriate in view of the implementation of the Decentralization Strategy 2016-2025, in the Public Finance Act, in the section concerning the relation of municipal budgets with the state budget, to state that municipalities should be provided with sources of own revenues in the amount of at least $10-15 \%$ of GDP. In this regard, the most suitable source is the natural person's income taxes. For this purpose, part of the natural person's income taxes - in the amount of about $10 \%$ to $20 \%$ - should be transferred to the municipalities. Of course, a serious study and impact assessment should be made so that this amount is explicitly determined.

\section{References}

1. Ganev, P., Aleksiev Y. (2018). Patyat kam fiskalna detsentralizatsiya: Spodelyane na danak obsht dohod $s$ obshtinite. Retreived from : https://ime.bg/var/images/IMEFiscal-Decentralization.pdf

2. Ministerstvo na regionalnoto razvitie i blagoustroystvoto (2016) Strategiya za detsentralizatsiya 2016-2025. Retrieved from : https://www.mrrb.bg/static/media/ups/articles/attachments/42e3960042715c84ef700aa a6af00cc6.pdf

3. Guziejewska. B. (2018). Normative versus positive approach to fiscal decentralisation and the measures of decentralisation. An analysis based on the example of selected countries of Central and Eastern Europe. Comparative economic research-central and Eastern Europe, 21(1), 101-117.

4. Slavinskaite, N., Davulis, G., Paleckis, K. (2015). Fiscal decentralization in the public sector of Lithuania: possibilities of development. International journal of contemporary economics and administrative sciences, 5(3-4), 67-84.

5. Finžgar, M., Oplotnik, Ž. J. (2013). Comparison of fiscal decentralization systems in EU-27 according to selected criteria. Lex localis - journal of local self-government, 11(3), 651-672.

6. Makreshanska-Mladenovska, S., Petrevski, G. (2020). Decentralisation and fiscal performance in Central and Eastern Europe. Post-communist economies, 79630.

7. Cheshmedzhieva, M., Mircheva, V. (2020). Administration of the Council of Ministers in the Republic of Bulgaria. In Studies in Humanities and Social Sciences: 5th International e-Conference on Studies in Humanities and Social Sciences Conference Proceedings (pp. 123-124). Belgrade: Center for Open Access in Science (COAS).

8. Goleva, V., Mircheva, V. (2020). Constitutional And Financial Legal Aspects Of The State Budget In The Republic Of Bulgaria. Economics \& Law, 2(1), 16-42.

9. Durana, P., Valaskova, K., Chlebikova, D., Krastev, V., Atanasova, I. (2020). Heads and Tails of Earnings Management: Quantitative Analysis in Emerging Countries. Risks, 8(2), 57.

10. Kliestik, T., Belas, J., Valaskova, K., Nica, E., \& Durana, P. (2020). Earnings management in V4 countries: the evidence of earnings smoothing and inflating. Economic Research-Ekonomska Istraživanja, 1-19.

11. Ministerstvo na regionalnoto razvitie i blagoustroǐstvoto (2014). Doklad za izpalnenieto na Strategiyata za detsentralizatsiya i na Programata za neynoto izpalnenie prez 2013

g.

Retrieved from 
https://www.mrrb.bg/static/media/ups/articles/attachments/2205ec5a336f15f6aff0881b fed69d75.pdf

12. Lukic, I., Martic, B., Vlaovic, D. (2014). Role and responsibilities of local management for governing and disposal of funds for financing of decentralized functions. Interdisciplinary management research. In Proceedings of the10th International Conference on Interdisciplinary Management Research (pp. 16-18). Croatia: Opatija.

13. Storonyanska, I., Benovska, L. (2017), Risks of administrative and financial decentralisation: theoretical hypotheses and empirical assessment. Economic Annals$X X I, 166(7-8), 76-79$.

14. Aristovnik, A. (2012). Fiscal decentralization in Eastern Europe: trends and selected issues. Transylvanian Review of Administrative Sciences, 37E, 5-22.

15. Vojinovic, B., Prochniak, M., Oplotnik, Z. J. (2015). International aspects of fiscal convergences on regional and local level. Lex localis-journal of local self-government, 13(3), 827-847.

16. Rodriguez-Pose, A., Kroijer, A. (2009). Fiscal decentralization and economic growth in Central and Eastern Europe. Growth and change. 40(3), 387-417.

17. Svyanevich, P. (2003). Osnovy fiskal'noy detsentralizatsii. Budapesht: Aktisz Studio.

18. Collective monograph (2018). Sustainable development \& competitiveness of regions. Plovdiv: Academic publishing house "Talent" University of agribusiness and rural development Plovdiv.

19. Shatrava, S. O., Khramtsov, O. M., Kolomoiets, N. V., Tyshchenkova, I. O. (2019). Specifics of budget decentralization in Ukraine. Financial and credit activity-problems of theory and practice, 1(28), 264-271.

20. Network of Associations of Local Authorities of South-East Europe (2012, March). Fiscal Decentralization Indicators for South-East Europe. Retrieved from : http://www.nalas.eu/knowledge-center/Fiscal-Decentralization-Indicators-for-SouthEast-Europe 